\title{
The Effects of Work-Family Conflict on Turnover Intention of Banks' Employees in Padang with Burnout as The Mediating Variable
}

\author{
Rini Sarianti ${ }^{1}$, Yuki Fitria ${ }^{2}$, Yunita Engriani ${ }^{3}$ \\ ${ }^{1}$ Dept. of Management, Faculty of Economics, Universitas Negeri Padang, Padang, Indonesia \\ $\square$ (e-mail) rini_sarianti@yahoo.com \\ 2Dept. of Management, Faculty of Economics, Universitas Negeri Padang, Padang, Indonesia \\ $\square$ (e-mail)yuki.fifit@gmail.com \\ 32Dept. of Management, Faculty of Economics, Universitas Negeri Padang, Padang, Indonesia \\ $\square$ (e-mail) yunitaengriani@gmail.com
}

\begin{abstract}
The study aims to examine the effect of work-family conflict on turnover intention of banks' employees in Padang with burnout as the mediating variable. The population of this study was all female employees at 7 conventional banks selected in the city, and the population number was 378 people. The sampling technique of this research was purposive sampling technique and the sample size was 100 people. The primary data were analyzed using regression analysis technique with a mediating variable and a causal step method with SPSS version 20 program. Based on the results of data processing, it can be concluded that work-family conflict has a significant effect on the turnover intention of banks' employees in Padang. Burnout is proven as a significant mediating variable of work-family conflict with turnover intention in banks in Padang.
\end{abstract}

Keywords: turnover intention, work-family conflict, and burnout

\section{Introduction}

The banking industry is currently experiencing a very high level of competition. Therefore, banks must be managed professionally in order to provide quality and high-value services. Moreover, the bank is one of the institutions needed to support "Advancing business and economy in the digital era". To anticipate tight competition conditions, banks must recruit qualified employees. However, employing qualified employees is not the only solution; the bank must also be able to retain these qualified employees. Organizational policies that are not in line with the expectations and the needs of employees will cause a desire to change the job (turnover intention).

According to Jaros et al. (1993) in Sumarto (2009), the turnover intention is the beginning of an employee's turnover behavior. Some of the symptoms that indicate the turnover intention are those specifically concerning employee behaviors, such as an increasing rate of absences, lack of productivity, the tendency to violate workplace rules, the tendency to oppose or protest the superiors, and an approach to handling responsibilities that is different from the usual (Novliadi, 2008).

The result of the research conducted by Tampi (2010) has shown that the turnover rate of banks' employees in Indonesia reaches $15-20 \%$ per year, while the survey conducted by PWC / Price Waterhouse Cooper (2012) stated that the turnover rate of banks' employees is $10-20 \%$. This number is higher than the turnover rate in the manufacturing industry, which is around $8 \%$ (Wulandari, 2008). To lower the employee turnover, it is very important for banks to know what causes the high turnover intention of employees within an organization.

Previous research has shown several factors that can affect turnover intention, such as organizational justice (Abu, 2010a; Ince and Gul, 2011; Lambert et al., 2010; Hassan and Hashim, 2011), job satisfaction (Shields and Ward, 2001; Lu et al, 2005), stress (Firth, Mellor, Moore, and Loquet, 2004), burnout (Goddart and O'Brien, 2003; Jourdain and Chenevert, 2010; Malik, Zaheer, Khan and Ahmed, 2010), and work-family conflict (Ghayyur, and Jamal, 2012; Thanacoody. et.al, 2009; and Haar, et.al, 2012). 
The intention to resign (turnover intention) is often associated with work-family conflict. Workfamily conflict can be interpreted as a form of role conflict where the demands of the role of work and family cannot be mutually aligned in some respects. The result of the research conducted by Apperson, et.al (2002) states that work-family conflict can occur both in men and women. However, several studies have shown that older women are more likely to experience work-family conflicts compared to men. This is due to the demand on women to work but the family does not lessen her workload as a wife and a housewife.

This work-family conflict phenomenon poses many negative impacts, either on the working woman itself, her family, or the organization where she works. Work-family conflict individually results in burnout (Thanacoody, et.al 2009). According to Poerwandari (2010), burnout is a condition of someone who is drained and loses mental and physical energy. Burnout usually occurs in the form of continuous physical fatigue and emotional exhaustion and it ultimately leads to an increase in turnover intention (Gayur, and Jamal 2012; Thanacoody, et.al 2009; Bloome 2010). Based on the description that has been explained on the background of the problem, it is interesting to do a research on this and to identify the influence of work-family conflict on the turnover intentions of banks' employees in Padang, with burnout as the mediating variable.

\section{Turnover Intention}

Turnover intention is an employee's tendency or intention to quit his job (Zeffane, 2004 and Ali, et al., 2010). According to Khan et al. (2014), the turnover intention is an employee's negative perception of his work that results in the potential to leave the organization if he feels displeasure and exhaustion at work. Turnover intention refers to the results of an individual's evaluation of the continuity of the relationship with his workplace but has not yet felt manifested in concrete actions (Hersusdadikawati, 2005). From these various opinions, it can be concluded that turnover intention is a negative perception of an employee in his work and it leads to the potential to leave the organization if he feels displeasure and exhausted at work.

There are many factors that influence the turnover intention. These factors include job satisfaction, organizational commitment, trust in the organization, job insecurity and job stress (Wijaya, 2010; Mellor et al., 2004; Moore, 2002; Rambur et al., 2003; and Arnold et al., 2010), low salaries and inflexible work schedules (Coomber \& Barriball, 2007; Hayes et al., 2006), career improvement prospects (Tzeng, 2002; Rambur et al., 2003), burnout (Tzeng, 2002), and work-family conflict (Noor and Maad, 2008; Sharafi and Shahrokh, 2012).

Several studies show that turnover intention is a predominant predictor of positive actual turnover (Lae and Liu, 2007). Furthermore, Bester (2012) explains that turnover intention is the final step in the decision-making process before one actually leaves the workplace. According to Abbasi and Hollman, 2000 (in Gosh et al., 2013), turnover is classified into 2 types, namely voluntary turnover, which is the intention of the employee itself to resign, and involuntary turnover, which refers to the dismissal of an employee by the organization (dismissal by superiors). Turnover intention discussed in this research is in the context of voluntary turnover. According to Abelson (1987) in Sumarto (2009), there are 3 indicators of intention to leave:

1. Thinking about quitting, that is when an employee feels that the job has resulted in burnout, or the organization does not pay attention to the welfare of its employees, which results in the employee's intention to quit his current job.

2. Perceived chance of leaving, i.e. an employee feels that he has the chance to leave the organization and thinks of this as the right decision.

3. Conviction decision to quit, i.e. the circumstances in which the employee is serious about quitting his job for a reason. 


\section{Work-Family Conflict}

Kahn, et al in Greenhouse and Beutel (1985) describes the concept of work-family conflict by using a role-play framework, in which the main determinant of an individual behavior is the behavioral expectations that others have toward them. Based on the framework, Kahn, et al defines work-family conflict as a form of conflict between roles in conflicting occupations and environments. Work-family conflict is also defined as the conflict that occurs in employees, who on one hand must perform responsibilities in the office, and on the other hand, she/ he must take care of the family.

Work-family conflict indicators as stated by Greenhaus and Beutell (1985) are divided into the following:

1. Time-based conflict

The time it takes to execute one of the demands on the job can reduce the time to run other demands.

2. Strain-based conflict

There is a pressure from one role to influence another role.

3. Behavior conflict

The final form of family-work conflict is a behavior-based conflict, in which certain patterns of behavior are not in accordance with expectations about behavior in other roles, e.g when the solutions for work problems are treated similarly with the solutions for family problems.

\section{Burnout}

Maslach (1993) in Anbar and Eker (2008) defines burnout as a psychological syndrome that consists of three dimensions: emotional exhaustion, depersonalization, and low personal accomplishment. Burnout causes people who were previously deeply committed to their work to be disappointed and lose interest and motivation. According to Mondy (2005), burnout is the most common factor causing the decision to quit the organization. It can be concluded that burnout is a psychological condition that occurs at an individual level. and it consists of three dimensions, namely emotional exhaustion, depersonalization, and reduced personal accomplishment.

Burnout is not necessarily similar to stress; however, the stress that has been accumulated will cause burnout (Miyazagi, 2000 in Lewin and Sager, 2008). Smith, Gill, Segal \& Segal (2008) describe the difference between stress and burnout, in which burnout workers will tend to remain silent and look powerless due to loss of motivation and enthusiasm that results in powerlessness. On the contrary, workers tend to become more active and emotionally aggressive in stressful situations. Both burnout and stress sufferers are experiencing problems especially at work, but the response is different. Prolonged stress can result in a burnout; however, burnout conditions experienced by workers are not necessarily caused by stress.

Maslach (1988) as the founder of Maslach Burnout Inventory-Human Service Survey (MBI-HSS) stated three burnout dimensions:

1. Emotional exhaustion is the depletion of emotional sources from within the individual which is characterized by feelings of frustration, despair, sadness, feeling overextended, irritable without a cause, easy to feel exhausted, depressed and feeling trapped in the work.

2. Depersonalization is the tendency of an individual to stay away from social environment, to be cynical, apathetic, and unfeeling to the environment and the people around him. This dimension describes burnout exclusively for works in the field of humanitarian service.

3. Reduction of Personal Achievement. Professional success is used to explain a satisfaction of past and present achievements. This dimension is more focused on work expectations and skills or the competence of a person in doing his job. Employees who demonstrate professional success are often top performers in their organizations and have confidence in their abilities. On the contrary, employees who lack professional success question their contribution and feel little to no job satisfaction. 


\section{Conceptual Framework}

Turnover intention is the beginning of an employee's turnover behavior. Based on the results of previous research, many factors can increase the turnover intention, one of which is work-family conflict. The intention to quit (turnover intention) is often associated with work-family conflict. Workfamily conflict can be interpreted as a form of role conflict where the demands of the role of work and family cannot be mutually aligned in some respects. Work-family conflict can occur in both men and women, but female employees are more likely to experience work-family conflicts compared to men.Work-family conflict individually results in burnout. Burnout is a condition of someone who feels drained and loses mental and physical energy. Burnout is usually in the form of continuous physical fatigue and mental exhaustion and it ultimately leads to an increase in turnover intention. Figure 1 below presents the conceptual framework of this study.

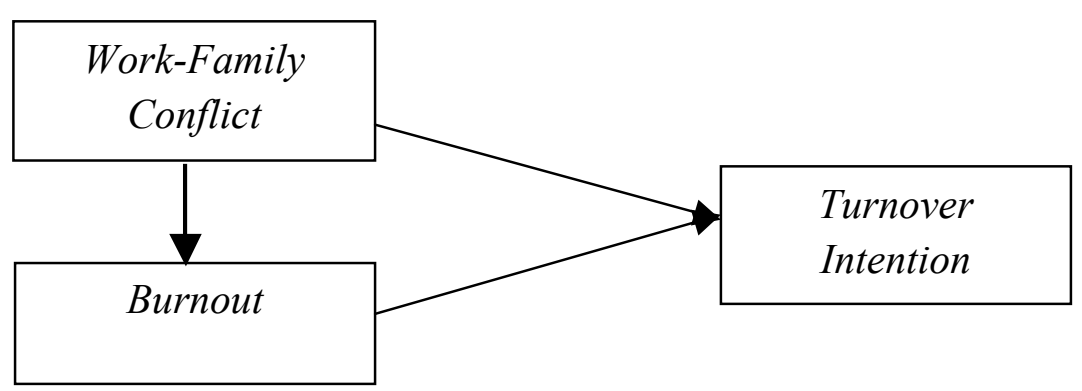

Figure 1 Conceptual Framework

The hypotheses formulated for this research are:

$\mathrm{H}_{1}$ Work-family conflict has an impact on the turnover intention of banks' employees in Padang

$\mathrm{H}_{2}$ Work-family conflict has an impact on the turnover intention of banks' employees in Padang with burnout as a mediating variable

\section{Methods}

The purpose of this research is hypothesis testing by using survey method. The data used were primary data collected through the distribution of questionnaires. This was because the research is a survey research where one of the advantages lies in generalization, and the more respondents used the better (Kerlinger \& Lee, 2000). The population in this study was all female employees in conventional banks in Padang. The sample was defined by the following criteria: 1) a female employee, 2) is married, and 3) have minimum 3 years of service. Through the Slovin formula, the sample size obtained in this study was 195.

Out of the 195 units of distributed questionnaires, only 100 questionnaires were eligible for further analysis after the questionnaires were checked and adjusted to the sample criteria. The data were then analyzed by using regression analysis with the mediating variable through the use of causal step method developed by Baron and Kenny (Suliyanto, 2011). The causal step method were solved by 3 equations as follows:

$$
\begin{array}{ll}
\text { Equation I } & : \hat{Y}=\alpha_{1}+c X \\
\text { Equation II } & : M=\alpha_{2}+a X \\
\text { Equation III } & : \dot{Y}=\alpha_{3}+c X+b M
\end{array}
$$

\section{Results and Discussion}

Before analyzing the data with regression analysis, a classical assumption testing was done which included normality, multicollinearity, and heteroscedasticity tests. After all assumptions were met, regression analysis was performed for hypothesis testing. To answer the hypotheses, regression analysis technique with the mediating variable through the use of causal step method was applied. The application of the causal step method was solved by using 3 equations in three stages. The first 
stage is for testing equation $\mathrm{I}$, which is to test the relationship between work-family conflict $(\mathrm{X})$ and turnover intention $(\mathrm{Y})$ variable. Through the use of SPSS version 20 program, the regression coefficients that were obtained can be seen in the following Table 1 .

Table 1 Regression coefficients equation I

Coefficientsa

\begin{tabular}{lllllll}
\hline Model & & \multicolumn{2}{c}{ Unstandardized Coefficients Standardized } & T & Sig. \\
& & Coefficients & & \\
\cline { 2 - 5 } & & B & Std. Error & Beta & 1.813 & 0.073 \\
\hline 1 & (Constant) & 0.445 & 0.245 & & 9.831 & 0.000 \\
\hline & WFC & 0.819 & 0.083 & 0.705 & & \\
\hline
\end{tabular}

Dependent Variable: TI

From table 1 above, the obtained regression coefficient is 0.819 , with a significant value of 0.0000 $<0.05$. Thus, there is a significant correlation between work-family conflict $(X)$ and turnover intention $(Y)$ with the equation of $Y=0.445+0.819 X$. Due to the first significant equation test result, the test was continued in the second stage (second equation). In the second equation, the correlation between work-family conflict $(X)$ variable and the mediating variable that is burnout $(M)$ was tested by using SPSS version 20 program. The obtained regression coefficients are as follows:

Table 2 Regression coefficients of equation II

Coefficients $^{\mathrm{a}}$

\begin{tabular}{|c|c|c|c|c|c|c|}
\hline \multirow[t]{3}{*}{ Model } & & \multirow{2}{*}{\multicolumn{2}{|c|}{$\begin{array}{l}\text { Unstandardized } \\
\text { Coefficients }\end{array}$}} & Standardized & \multirow[t]{3}{*}{$\mathrm{t}$} & \multirow[t]{3}{*}{ Sig. } \\
\hline & & & & Coefficients & & \\
\hline & & $\bar{B}$ & Std. Error & Beta & & \\
\hline \multirow[t]{2}{*}{1} & (Constant) & -0.085 & 0.172 & & -0.493 & 0.623 \\
\hline & WFC & 0.962 & 0.058 & 0.857 & 16.481 & 0.000 \\
\hline
\end{tabular}

Dependent Variable: BO

From the result of data processing, the regression coefficient is 0,962 with a significant $0,000<0,05$. Thus, it can be concluded that there is a significant correlation between work-family conflict $(X)$ and burnout (M). The regression equation is as follows: $M=-0.085+0.962(X)$.

Since the results of the second equation regression are eligible for further test, the test was continued to the third equation. In the third equation, the effect of work-family conflict $(X)$ and burnout $(\mathrm{M})$ variable to the turnover intention $(\mathrm{Y})$ were tested with the use of SPSS program version 20. The obtained regression coefficient is as follows:

Table 3 Regression coefficients of equation III

Coefficients $^{\mathrm{a}}$

\begin{tabular}{|c|c|c|c|c|c|c|}
\hline \multirow[t]{2}{*}{ Model } & & \multicolumn{2}{|c|}{$\begin{array}{l}\text { Unstandardized } \\
\text { Coefficients }\end{array}$} & \multirow{2}{*}{$\begin{array}{l}\text { Standardized } \\
\text { Coefficients } \\
\text { Beta }\end{array}$} & \multirow[t]{2}{*}{$\mathrm{t}$} & \multirow[t]{2}{*}{ Sig. } \\
\hline & & B & Std. Error & & & \\
\hline \multirow[t]{3}{*}{1} & (Constant) & 0.473 & 0.240 & & 1.974 & 0.051 \\
\hline & WFC & 0.494 & 0.158 & 0.425 & 3.124 & 0.002 \\
\hline & $\mathrm{BO}$ & 0.338 & 0.141 & 0.327 & 2.403 & 0.018 \\
\hline
\end{tabular}

Dependent variable: TI

Based on the table above, it is shown that the regression coefficient of work-family conflict $(X)$ is 0.494 with a significant $0.002<0.05$. Furthermore, the regression coefficient of burnout $(\mathrm{M})$ is 0.338 with a significant value of $0,018<0,05$. Thus, it can be concluded that both variables of work-family conflict and burnout have a direct and significant effect on turnover intention. Thus, if work-family conflict and burnout perceived by employees increase, then the turnover intention of banks' 
employees also increases. Based on the data processing, the summary model of the third equation is also obtained, as seen below:

Table 4 The model summary

\begin{tabular}{llllllll}
\hline $\mathrm{R}$ & $\mathrm{R}$ Square & $\begin{array}{l}\text { Adjusted R } \\
\text { Square }\end{array}$ & $\begin{array}{l}\text { Std. Error of } \\
\text { the Estimate }\end{array}$ & $\begin{array}{l}\mathrm{R} \text { Square } \\
\text { Change }\end{array}$ & F Change & df2 & $\begin{array}{l}\text { Sig. F } \\
\text { Change }\end{array}$ \\
\hline $0.724^{\mathrm{a}}$ & 0.525 & 0.515 & 0.66434 & 0.525 & 53.565 & 97 & 0.000 \\
\hline Source: Processed primary data (2017) & & & & &
\end{tabular}

Based on Table 4 above, it is found that the adjusted $\mathrm{R}$ square is equal to 0,515 . It can be concluded that the contribution of work-family conflict $(X)$ and burnout $(\mathrm{M})$ variable to turnover intention $(\mathrm{Y})$ variable is $51.5 \%$. The rest $48.5 \%$ of the turnover intention $(\mathrm{Y})$ variable can be explained by other factors that are not included in this study. Furthermore, work-family conflict $(X)$ and burnout $(\mathrm{M})$ variables together have a significant influence on the turnover intention $(Y)$ variable, which can be seen from the sig. F change value of $0,000<0,05$.

In the first regression equation, the regression coefficient of work-family conflict $(X)$ variable in relation to the turnover intention $(\mathrm{Y})$ without entering the mediation variable into the equation is equal to 0,819 . However, after entering the burnout variable as a mediating variable into the third equation, there is a decrease in regression coefficient of work-family conflict $(X)$ variable from 0.819 to 0.494. This means that burnout is expressed as a partial mediating variable between work-family conflict $(\mathrm{X})$ and turnover intention $(\mathrm{Y})$. Through the Sobel test, it is proven significantly that burnout is a mediating variable of the relationship between work-family conflict $(X)$ and turnover intention (Y). Therefore, it is concluded that if the employees' perceived work-family conflict is high, it can increase employees' burnout, which in turn can lead to the behavior of turnover intention on the banks' employees in Padang.

\section{Discussion}

Based on the results of the above analysis, it is concluded that the work-family conflict variable has a direct, positive and significant effect on the turnover intention. This means that if the employees' perceived work-family conflict increases, it can increase the turnover intention of banks' employees. In addition, burnout also has a positive and significant impact on the turnover intention. If the burnout of employees increases, it can lead to an increase in the turnover intention of banks' employees. Furthermore, it is also proven significantly that burnout variable formed a partial mediation relationship between work-family conflict and turnover intention.

The results of this study are in line with the research by Ghayyur, and Jamal (2012), Thanacoody et al. (2009), and Haar, et al. (2012), which state that turnover intention is often associated with workfamily conflicts, and that work-family conflict has a positive and significant effect on turnover intention. The emergence of conflict is due to an imbalance in performing the workload and the family role which makes employees feel uncomfortable, and ultimately leads to turnover intention (Ida Ayu and I Gusti Ayu, 2016).

Work-family conflict individually results in burnout (Thanacoody et al., 2009). Research conducted by Laeeque (2014) on employees of the banking sector in Pakistan has also proven that work-family conflict, both from family interference with work and work interference with family, has a positive and significant impact on job burnout. The burnout is usually experienced by employees in the form of continuous physical fatigue and mental exhaustion, and it ultimately leads to an increase in turnover intention (Gayur, and Jamal, 2012; Thanacoody et al., 2009; Bloome, 2010).

\section{Conclusions}

Based on the results of data processing, it is concluded that work-family conflict has a positive and significant effect on the turnover intention of banks employees in Padang. Burnout is proven 
significantly and positively as a mediating variable of work-family conflict and turnover intention in banks in Padang.

\section{Acknowledgments}

We would like to express our gratitude to Indonesian government for funding this research.

\section{References}

Atheya, R., \& Arora, R. (2014). Stress and its brunt on employee's work-life balance (WLB): A conceptual study. IOSR Journal of Humanities and Social Science (IOSR-JHSS). 19(03), 57-62.

Chin, W. W., and Gopal, A. (1995). Adoption Intention in GSS: Importance of Beliefs. Data Base Advances, 26, 42-64.

Cooper Cary \& Alison Straw., 1995. Stress Management yang Sukses. Jakarta: Kesain Blanc.

Costa, G. E. Haus and R. Stevens. (2010). Shift work and cancer-Considerations on rationale, mechanisms, and epidemiology. Scandinavian Journal of Work, Environment \& Health, 36(2), 163179.

Eviaty, Satiadarma, M, P. (2005). Persepsi terhadap dukungan sosial rekan sekerja dan gejala burnout (Studi pada perawat unit perawatan intensif). Jurnal Phronesis, 7(2), 102-118.

El- Jardali, F., Dimassi, H., Dumit, N., Jamal, D., \& Mouro, G. (2009). A national cross-sectional study on nurses' intent to leave and job satisfaction in Lebanon: Implications for policy and practice. BMC nursing, 8(1), 3.

Firth, L., Mellor, D.J., Moore, K. A. \& Loquet, C. (2004). How can managers reduce employee intention to quit? Journal of Managerial Psychology, 19, (1/2), 170-180.

Gary, Dessler (2010). Manajemen Sumber Daya Manusia. 10 th Edition. Jakarta: PT. Indeks.

Ghozali, Imam (2006). AplikasiAnalisis Multivariate dengan Program SPSS, Badan Penerbit Universitas Diponegoro.

Gill, A., Flaschner, A. B. \& Shachar, M. (2006). Mitigating stress and burnout by implementing transformational-leadership. International Journal of Contemporary Hospitality Management. 18(6), $1-16$.

Greenberg, J., \&Baron A. R. (2003). Behaviour in Organisations. Prentice Hall, 8, 188-215.

Hair, J., \& Black, et al., (2006). Multivariate Data Analysis, New Jersey: Prentice Hall.

Hasibuan, Malayu S. P. (2009). Manajemen Sumber Daya Manusia Edisi Revisi. Jakarta: BumiAksara.

Hersusdadikawati. (2005). Pengaruh Kepuasan gaji terhadap keinginan untuk berpindah kerja, dengan komitmen organisasional sebagai variabel intervening (Studi empiris pada dosen akuntansi perguruan tinggi swasta Jawa Tengah). Jurnal Studi Manajemen dan Organisasi, 2(1).

Ivancevich, M John, Konopaske Robert, T. Matteson Michael. (2011). Perilaku dan Manajemen Organisasi. Jakarta: Erlangga.

Jogiyanto, H.M (2005). Metodologi Penelitian Bisnis: Salah Kaprah, dan Pengalaman-Pengalaman, BPFE, Yogyakarta.

Jourdain, G., \&Chênevert, D. (2010). Job Demands-Resources, Burnout and Intention to Leave the Nursing Profession: A questionnaire Survey. International Journal of Nursing Studies, 47(6), 709722.

Lailani, Freshti. (2012). Burnout pada perawat ditinjau dari efikasi diri dan dukungan sosial. Jurnal Talenta Psikologi. 1(1).

Lewin, J. E., \& Sager, J. K. (2008). Salesperson burnout: A test of the copying-mediational model of social support. The Journal of Personal Selling \& Sales Management, 28 - 246. Lewin, J. E., Sager, J. K. (in press).

Lu H, Barriball KL, Zhang X \& While AE (2011). Job Satisfaction among hospital nurses revisited: A systematic review. International of Nursing Studies, 49, 1017 - 1038.

Luthans, Fred. (2006). Perilaku Organisasi. 10 th Edition. Penerbit Andi, Yogyakarta. 
Malik, M.I., Zaheer, A., Khan, M.A., \& Ahmad, M. (2010). Developing and Testing a model of burnout at work and turnover intensions among doctors in Pakistan. International Journal of Business and Management, 5(10): 234-244.

Maslach, C. (1982). Burnout: The Cost of Caring. Englewood Cliffs, NJ: Prentice-Hall.

Mellor, David J., Moore, Kathleen A., \& Loquet C. (2004). How can manager reduce employee intention to quit. Journal of Managerial Psychology, 19(2), 170-187.

Moody, R. C., \&Pesut, D. J. (2006). The motivation to care application and extension of motivation theory to professional nursing work. Journal of Health Organization and Management, 20(1), 15-48.

Newstead, S. E, Brandon, P. S. H, Evans, J \& Dennis, L. (2002). Using the Psychology of Reasoning to Predict the Difficulty of Analytical Reasoning Problem in S.H Irvine and P.C Kyllonen (Eds). Item Generation for Test Development (pp 35-51). Mahwah N.J: Lawrence Erlbaum Associates.

Novliadi, F. (2008). Intentensi turnover karyawan ditinjau dari budaya perusahaan dan kepuasan kerja. Undergraduate Thesis. Universitas Sumatera Utara, Medan.

Tampi, M. R. (2010). Kerja di bank, untung besar, stres level tinggi. Retrieved on 17 October 2012 Retrieved from http://female.kompas.com/read/2010/10/16/16302384/Kerja.di.Bank.Untung. Besar.Stres.Level.Tinggi

Greenhaus, J. H., \& Beutell, N. J. (1985). Sources of conflict between work and family Roles. Academy of Management Review, 10, 76-78.

J. M. Haar, M. Roche, \& D. Taylor. (2012). Work-family conflict and turnover intentions of indigenous employees: The importance of the whanau/family for Maori. The International Journal of Human Resource Management, 23, 2546-2560.

M. Ghayyur, \& W. Jamal. Work-family conflicts: A case of employees' turnover intention.

International Journal of Social Science and Humanity, 2 (2012) 168-174.

Mulki, J. P., Jaramillo, J.F., \& Locander, W. B. (2008). Effect of ethical climate on turnover intention: Linking attitudinal and stress theory. Journal of Business Ethics, 78, 559-574.

Noraini, M. N. (2004). Work-family conflict, work- and family-role salience, and women's well-being. The Journal of Social Psychology, 144(4), 389-405.

Paille, P. (2011). Stressful Work. Citizensh.

Papalia, D. E., Old, S. W., \& Feldman, R. D. (2007). Human Development. 10th ed. New York: McGraw Hill.

Thanacoody, P. R., Bartram, T., \& Casimir, G. (2009). The effects of burnout and supervisory social support on the relationship between work-family conflict and intention to leave: A study of Australian cancer workers. Journal of Health Organization and Management, 23, 53-69.

Poerwandari, K. (2010). Mengatasi burnout di tempat kerja. Retrieved from http://www.portahr.com/ tips/2id223.html. Diakses 2 April 2016.

[PWC] Price Waterhouse Coopers. 2012. Indonesia Banking Survey. Jakarta (ID): PWC.

R.J. Bloome, A. V. Rheede, \& D. M. Tromp. (2010). Work-family conflict as a cause for turnover intentions in the hospitality industry. Tourism and Hospitality Research, 10, $269-285$.

Robbins, Stephen. P., \& Judge, Timothy A. (2011). Organizational Behavior. Fourteenth Edition. New Jersey: Person Education, Inc.

Schwepker. C. H., Jr. (2001). Ethical climate's relationship to job satisfaction, organizational commitment, and turnover intention, in the salesforce. Journal of Business Research, 54, 39-52.

Sekaran, Uma (2003), Research Methods for Business: A Skill Building Approach, New York-USA: John Wiley and Sons, Inc.

Sumarto. (2009). Meningkatkan komitmen dan kepuasan untuk menyurutkan niat keluar. Jurnal Manajemen Kewirausahaan, 11(2).

Umar, Husein. (2009). Metode Penelitian untuk Skripsi dan Tesis Bisnis. Jakarta: Rajawali Press.

W. G. Howard, H. H. Donofrio, J. S. Boles. Inter-domain work-family, family-work conflict and police work satisfaction. Policing: An International Journal of Police Strategies \& Management, 27 (2004) 380-395. 
Yang, N., Chen, C. C., \& Zou, Y. (2000). Source of work-family conflict: A Sino-U.S. comparison of the effect of work and family demands. Academy of Management Journal, 43(1), 113-123.

Zeffane, R. (2004). Employee turnover: A meta-analysis and review with implication for research. Academy of Management Review, 11(1), 55-70. 